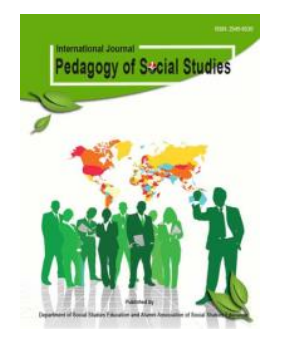

\author{
International Journal Pedagogy of Social Studies
}

\title{
The Role Paskibra Extracurricular in Developing Students` Social Skills
}

\author{
Rizky Dwi Astuti ${ }^{1}$, Dadang Sundawa ${ }^{2}$, Eded Tarmedi $^{3}$ \\ Education of Social Studies Study Program, Faculty of Social Sciences Education \\ Universitas Pendidikan Indonesia, Bandung, Indonesia
}

\begin{abstract}
This study aims to describe the role of Paskibra extracurricular in an effort to develop students' social skills seen from indicators of social skills, namely the ability to help each other, the ability to lead and be led, the ability to cooperate, the ability to respect others, the ability to obey rules (discipline), the ability to handle responsibility, the ability to convey opinion, the ability to be a responsive listener, and the ability to confidently ask questions. This study uses a qualitative approach with descriptive research methods implemented at SMPN 45 Bandung. The data in this study were obtained from observation, interviews, documentation studies and literacy studies. The results of the study indicate that Paskibra can play a role in developing students' social skills through various activities carried out by Paskibra extracurricular, namely routine training activities that are able to develop responsible and disciplined attitudes; the activity of providing Paskibra materials that can foster a sense of love for the homeland and nationalism; the participation of students in competitions that can foster students to help each other, cooperate, and be brave; joint training activities that can train communication skills, confidence and mutual respect; Diklatsar activities that can develop the spirit of leadership and cooperation, as well as social service activities that can instill social caring and empathy. Participants students who follow Paskibra extracurricular have good social skills. This can be seen from the change in the positive attitude of students towards the surrounding environment.
\end{abstract}

Keywords: Social Skills, Extracurricular, Paskibra.

Correspondence. rizkydwiastuti25@gmail.com

Article Historv. Received January 2020, Received in revised April 2020, Accepted June 2020

C2020. International Journal Pedagogy of Social Studies. Department of Social Studies

\section{A. INTRODUCTION}

Important social skills to develop in learners as early as possible. Students who have social skills will be easier to adapt to the surrounding environment, so it can be used as a student's capital to socialize with the community and interact with others. Kelly. et al. (Ramadhani, 2004, p. 58), Social skills are the behaviors learned, which individuals use in interpersonal situations to acquire or maintain the strengthening of their environment.

Social skills can not only be developed in learning activities in the classroom, but also through extracurricular activities conducted by the school. This is in line with the Peraturan Menteri Pendidikan dan Kebudayaan Republik Indonesia No. 62 the year 2015, stating that the potential development of learners as designed in national education objectives can realize the conduct of Which is one of the activities in the curricular program. Extracurricular activities can facilitate the development of potential learners into the development of talents, interests, and creativity as well as the ability to communicate and cooperate with others. 
The value that is learned in Paskibra extracurricular can develop attitudes and social skills in learners. Therefore, education is not only obtained by learners in the teaching and learning activities in the classroom, but students can participate in educational activities outside of class such as by following a Paskibra extracurricular. By participating in these extracurricular activities, students can gain experience from a variety of activities to train the interaction between members of learners, discipline, responsibility, help each other, and cooperate which is an aspect of social skills.

Based on the results of observations conducted by researchers in SMP Negeri 45 Bandung, visible social skills in learners are still low. Researchers observe some problems related to the lack of social skills of students including most students still have apathy to the problems in the surrounding environment. Students tend to be selfseeking and lacking the ability to cooperate.

Based on the results of the study of literate researchers low social skills in students can be addressed using various ways including First, according to Alwansyah, et al. (2015, p. 12) Low social skills can be solved using a simulated model. Secondly, based on the results of the study Ningsih, M.P. (2014, p. 71), the effectiveness of the use of project methods in improving the social skills of learners showed an increase of $18 \%$. Third, according to Cincin, A. (2018), The establishment of social skills can be developed through the extracurricular PMR. Activities in the extracurricular PMR can change the attitude of the students as well as more high concern, skills in collaboration, attitude each other, skills to divide togetherness, solidarity, and responsibility Social. Fourth, according to Saputra (2016, p. 12) learners who participate in the extracurricular activities of Paskibra will have better social skills or social competence compared to students who do not participate in extracurricular activities Paskibra. If viewed from the mean value, students who follow the co-curricular Paskibra have a higher level of social competence that is with a mean value of 91.84 compared to teenagers who do not follow the Paskibra extracurricular of 83.98, By using the social competency indicators such as Asertif, empathy, and responsibility.

Based on the above exposure, it can be concluded there are some problems related to low social skills in students in SMP Negeri 45 Bandung with traits apathy, individualist, lack of ability to cooperate, low attitude Help each other, lack respect for others and low student discipline behaviour and from a variety of solutions that have been displayed based on past research Then to overcome such problems researchers will use role models in developing social skills, namely by utilizing activities in Paskibra extracurricular. For that, researchers are interested in researching the title "The Role Of Paskibra Extracurricular In Developing Students Social Skills ".

\section{B. LITERATURE REVIEW}

Extracurricular activities aim to develop one of the subjects of interest in the students. Various extracurricular fields can be followed by learners such as sports, arts, Scout and a variety of skills organized by the school outside the regular lesson hours. According to Peraturan Menteri Pendidikan dan Kebudayaan Republik Indonesia, Number 62 years 2014 pasal 1 about extracurricular activities mention that extracurricular activities are curricular activities conducted by learners outside the hours of intracurricular study and curricular activities under the guidance and supervision of education units. The function of extracurricular activities described by Sumarna, M. (2006, p. 10) is an extracurricular activity intended to further relate to the knowledge gained in the curriculum program with the circumstances and needs of the environment. The expected objectives of the implementation of the flag ceremony at the school according to Gunawan (2012, p. 272) are:

a. Familiarize yourself with being orderly and disciplined.

b. Familiarize yourself with a neat look.

c. improve lead ability.

d. Familiarize yourself with willingness and cooperation. 
e. Foster solidarity and cooperation.

f. Improv the spirit of nationality.

Based on the exposure it appears that there is a connection between paskibra extracurricular and social skills. According to Sjamsuddin and Maryani (2008, p. 6) Social skills are an ability to be proficient in action, able to search, choose and manage information, able to learn new things that can solve daily problems, able to Having communication skills both oral and written, understand, appreciate, and able to cooperate with other people in the compound, able to transform academic ability and adapt to the development of the global community. According to Fatimah and Enung (2006, p. 94), social skills are the ability to overcome all problems arising from the interaction with the social environment and able to present themselves by the rules and norms.

The social skill aspects that students need to have according to Jarolimek, J. (1977, p. 208) are;

a. living and working together, taking turns; respecting the rights of others; being socially sensitive

b. learning self-control and selfdirection

c. sharing ideas and experiences with others.

The statement shows that the social skill aspects that the students must have are:

a. The skills of living together and in cooperation, able to put themselves in the social environment, appreciate others

b. Self-control skills and social control

c. Skill to exchange thoughts and experiences with others, so create a pleasant atmosphere for each member of the group.

Based on some aspects of social skills above, researchers refer to developing social skills indicators in this study, as follows:
Table 2.1. Social skills Indicators

\begin{tabular}{|c|c|}
\hline $\begin{array}{l}\text { Aspects/dimensio } \\
\text { ns of social skills }\end{array}$ & $\begin{array}{r}\text { Soci } \\
\text { Ind }\end{array}$ \\
\hline $\begin{array}{l}\text { 1. Skills to live } \\
\text { together and } \\
\text { cooperate, able } \\
\text { to put yourself } \\
\text { in the social } \\
\text { environment, } \\
\text { appreciate } \\
\text { others. }\end{array}$ & $\begin{array}{l}\text { 1. The Ability to } \\
\text { help each other } \\
\text { 2. The ability to } \\
\text { Lead and be Led } \\
\text { capability } \\
\text { 3. Ability to } \\
\text { cooperate } \\
\text { 4he Ability to } \\
\text { respect others }\end{array}$ \\
\hline 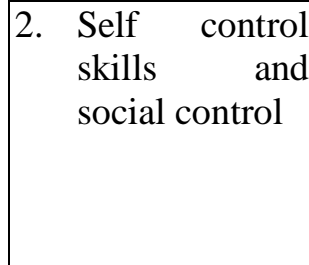 & $\begin{array}{l}\text { 1. The Ability to } \\
\text { obey rules } \\
\text { (discipline) } \\
\text { 2. The ability to } \\
\text { handle } \\
\text { responsibility }\end{array}$ \\
\hline 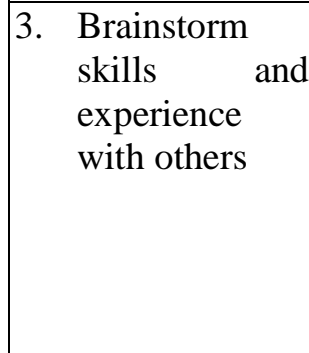 & $\begin{array}{l}\text { 1. The ability to } \\
\text { convey opinio } \\
\text { 2. the ability to be } \\
\text { a responsive } \\
\text { listener } \\
\text { 3. the ability to } \\
\text { confidently ask } \\
\text { questions }\end{array}$ \\
\hline
\end{tabular}

Also, the research is based on previous research conducted by several researchers who are closely related to the research that researchers review. This is done to assist researchers in obtaining referrals from previous research that pertinent research that is designed by researchers to overcome the research problem. Some previous research results that can be used as consideration are:

First, Antin Cincin (2018) titled "The Establishment of social skills students in the Red Cross extracurricular activities youth in SMP Negeri 1 Bandung". The results of this study show that the Red Cross extracurricular adolescents play a role in shaping the students ' social skills.

Secondly, Eko Saputra (2016) conducted research titled "Social Competence in adolescents who follow the extracurricular Paskibra and Tdak follow the Kestrakurikuler Paskibra". When viewed from the value of mean the results of the study showed that adolescents who follow Paskibra have a higher level of social 
competence of 91.84 compared to teenagers who do not follow Paskibra by 83.98. Third, Prima Pramesty Gantina (2016) titled The Role of Paskibra extracurricular activities to prevent student brawl ". The results of this research show that the co-curricular Paskibra teaches discipline and love for a sustainable homeland to prevent the occurrence of the brawl between students.

Based on the explanation above, some of the previous research can be used as a referral for researchers to facilitate research.

\section{METHOD}

This study used a qualitative approach with a descriptive research method conducted in SMP Negeri 45 Bandung. In this study, the technique of selection of data sources used is purposive sampling. The selection of participants as the subject of this research is conducted based on the consideration of objectives that want to be achieved so that the selection of participants is based on parties deemed able to provide information and facilitate researchers in explaining objects and situations. The subject is considered to be a speaker in this study, Paskibra extracurricular contractor, Paskibra extracurricular coach, Paskibra's Kestrakurikuler member and teacher of the subject IPS. The Data in this study was obtained using observation techniques, interviews, documentation studies, and literacy studies.

The data analysis techniques used in this qualitative study are data reduction, data presentation, and concluding. The data validation is done to increase the validity and credibility of the results of qualitative descriptive research by performing an extension of observations, improving persistence, data triangulation, reference materials and using the member check.

\section{RESULTS AND DISCUSSION}

Results and discussion in this study described the results of research conducted in SMP Negeri 45 Bandung using observation techniques, interviews, and documentation studies.

Based on the results of data analysis found that the general condition of the social skills of students in SMP Negeri 45 Bandung before following the Paskibra extracurricular is low. This is based on the findings that the learners who enter the VIIclass level are the transitional period of elementary school so that generally the condition of the students ' social skills still looks less good. The character of the students before following the Paskibra which is generally at the beginning of class VII is still having a rigid attitude, hesitant, less disciplined, difficult to associate, shy to act, less caring among friends and less disciplined.

Low social skills can be improved by learning. As explained by Kelly, et al. (Ramadhani, 2004. p. 58), stating that social skills are the behaviors learned, which individuals use in interpersonal situations to exercise or nurture the influence of their environment.

The social skills of a trait that is not carried out from birth, but the Social skills are a behavior that is formed from learning outcomes that are beneficial for individuals to interact, communicate, adapt and nurture good relationships in the school environment and community environment. As the explanation by Kurniati (2010, p. 35) explains that social skills are a primary necessity that children need to have for selfreliance on the next level of life, this is beneficial in everyday social life In the family environment, or the surrounding environment.

Paskibra extracurricular efforts in developing social skills learners in SMP Negeri 45 Bandung is to design a program of extracurricular activities Paskibra and implement a variety of Paskibra activities program with Involving various parties, namely the coach, trainer, leader of the force and members of Paskibra so that the program will be carried out well.

Based on the results of research researchers obtained that there is a variety of paskibra extracurricular activities performed either routinely or periodically. Such activities include; 1) Exercise routine, 2) material activities about Paskibra, 3) combined exercises, 4) DIKLATSAR/Exercise basic Leadership, 5) 
competition activities, 6) The demonstration of Paskibra extracurricular, 7) social duty. The involvement of students in various extracurricular activities of Paskibra can train themselves to learn the things about the nation of Indonesia. Paskibra extracurricular not only teach students to limit the red-white flag, but more than that in the extracurricular activities of students are also built to have a spirit of leadership, discipline, courtesy and, Love Homeland. As the purpose of the Paskibra extracurricular in the Paskibra activities program in SMP Negeri 45 Bandung school year 2018/2019 namely:

a. Familiarize yourself and discipline

b. Familiarize yourself with the appearance of neat

c. Promote leadership attitudes

d. To foster solidarity and cooperation

Thus it can be concluded, that Paskibra extracurricular activities play an important role in educating, nurturing and training learners to have discipline, mutual help, leadership, responsible, dare to speak And caring about our fellow human beings because this is where there are various good social values.

The Paskibra extracurricular is one of the best-rated extracurricular in SMP Negeri 45 Bandung. This is evident from the various achievements that have been achieved by Paskibra extracurricular in following various Paskibra races both in the city and national, thus causing extracurricular paskibra has several members Other extracurricular in the school. The participation of students in Paskibra extracurricular activities has a positive impact on both oneself and others surrounding it.

Paskibra extracurricular activities are not only able to develop the potential, interests, and talents of learners as stated by Asmani (2011, p. 62) That extracurricular activities are educational activities outside of subjects and lessons Counseling to help students develop according to their needs, potential talents and interests through activities that are specifically hosted by educators and or educational personnel who are capable and competent in school.
Moreover, learners who participate in Paskibra extracurricular activities can have a positive impact on developing attitudes, character, skills and social values that can be applied in daily life. As stated by Wiyani, N.A. (2013, p. 108), extracurricular activities are educational activities conducted outside of face to face lessons. These activities are conducted both inside and outside the school environment to expand knowledge, improve skills and internalize values, religious rules, and social norms.

Efforts undertaken by post-curricular Paskibra through various activities can result in better student social skills change. This is evident from the findings of the researchers indicating the positive attitudes of the students after following various Paskibra extracurricular activities such as the increase in the ability to help each other, lead and led, cooperate , respecting others, complying with the rules (discipline), responsibility, ability to convey opinions, ability to be responsive listeners and the ability to ask questions, courtesy and have a high sense of solidarity.

\section{E. CONCLUSION}

Based on some of the findings that have been outlined, overall it is elaborated that the existence of Paskibra extracurricular in SMP Negeri 45 Bandung has the role of the construction of the character of Paskibra extracurricular members in an effective Develop a student's social skills in particular and students of SMP Negeri 45 Bandung generally. As for the conclusion in this study is as follows;

First, the general condition of the social skills of students before following the extracurricular Paskibra, generally are students who just entered junior high school class VII and in particular, the students of the Paskibra newly merged into Member Paskibra. In general, the students ' social skills are still low where the students still have deficiencies in some attitudes such as lack of discipline, high individualist taste, apathy, difficult to associate, less 
responsible, and less Have a sense of selfconfidence.

Secondly, Paskibra extracurricular efforts to respond to the general conditions of low social skills of students, through the implementation of a variety of activities, such as the extracurricular program of Paskibra that has been planned in the annual program. A program such activities are; Routine training, activity giving participants the participation of students in race activities, combined exercises, training activities, and social duties. Paskibra's extracurricular activities are one of the school's efforts to develop the potential of learners, especially in developing social skills.

Thirdly, the results of the students ' social skills after joining Paskibra's extracurricular activities appear to be changing attitudes towards the better. Changes in the attitude include the attitude of obeying the rules (discipline), cooperation, help each other, appreciate others, tolerance, confident, brave to public speaking, dare to ask questions, independent, become listeners who are responsive, courteous and has a high sense of solidarity.

The results of the students ' social skills after joining Paskibra's extracurricular activities appear to be a change in the direction of a better attitude. Changes in the attitude include the attitude of obeying the rules (discipline), cooperation, help each other, appreciate others, tolerance, confident, brave to public speaking, dare to ask questions, independent, become listeners who are responsive, courteous and has a high sense of solidarity. The change of positive attitude is a form of social skills that students have after joining Paskibra extracurricular activities.

\section{REFERENCES}

Alwansyah, et al. (2015). Meningkatkan Keterampilan Sosial Siswa dengan Menggunakan Model Simulasi. [online]. Diakses dari http://jurnal.fkip.unila.ac.id/index.ph p/JSS/article/view/9254. Lampung: Universitas Lampung.
Asmani, J.M. (2011). Buku Panduan Internalisasi Pendidikan Karakter Sekolah. Jogjakarta: Diva Press.

Cincin, A. (2018).Pembentukan Keterampilan Sosial Siswa Dalam Kegiatan Ektrakurikuler Palang Merah Remaja di SMP 1 Negeri Bandung. Universitas Pendidikan Indonesia, Bandung.

Fatimah, P., \& Enung, W,. (2006). Psikologi Perkembangan: Perkembangan Peserta Didik. Bandung: CV Pustaka Setia.

Gunawan, H. (2012). Pendidikan Karakter, Konsep dan Implementasi. Bandung: Alfabeta.

Jarolimek, J. (1977). Social Studies Competencies and Skills. New York: MCMillan.

Kemendikbud. (2015). Peraturan Menteri Pendidikan dan Kebudayaan Republik Indonesia No. 62 tahun 2015 Tentang Kegiatan Ekstrakulikuler. Jakarta: Kemendikbud.

Kurniati, E. (2010). 30 Permainan Jawa Barat dan Peranannya dalam Mengembangkan Keterampilan Sosial. Bandung: PGPAUD UPI.

Ningsih, M.P. (2014). Efektivitas Penggunaan Metode Proyek dalam Meningkatkan Keterampilan Sosial Peserta Didik. Universitas Pendidikan Indonesia, Bandung.

Pramesty G.P.(2016).Peranan Kegiatan Ekstrakulikuler Paskibra untuk Mencegah Tawuran Pelajar. Universitas Pendidikan Indonesia, Bandung.

Program Kegiatan Ekstrakurikuler Paskibra Tahun Ajaran 2018/2019. SMP Negeri 45 Bandung.

Ramadhani, I. (2004). Keterampilan Sosial Remaja. Jakarta: Prenada Media Group.

Saputra, E. (2016). Kompetensi Sosial Pada Remaja yang Mengkuti Ekstrakurikuler Paskibra dan Tidak Mengikuti Ekstrakurikuler Paskibra. [online]. Diakses dari http://eprints.umm.ac.id/34258/1/jipt ummpp-gdl-ekosaputra-43409-1- 
kompeten-r.pdf. Fakultas Psikologi, Universitas Muhammadiyah, Malang. Sjamsuddin, H. dan Maryani, E. (2008). Pengembangan Pembelajaran Meningkatkan Keterampilan Sosial. Jurnal penelitian Vol.9 No. 1.
Sumarna, M. (2006). Perbandingan Antara Siswa Yang Menjadi Pengurus dan Bukan Pengurus OSIS Dalam Pemanfaatan Waktu Luang Dan Prestasi Belajar di SMK N 6 Bandung. Universitas Pendidikan Indonesia, Bandung.

Wiyani, N.A. (2013). Manajemen Kelas. Yogjakarta : Ar-Ruzz Media. 
RIZKY DWI ASTUTI, DADANG SUNDAWA, EDED TARMEDI/ The Role Paskibra

Extracurricular in Developing Students`Social Skills

53 | International Journal Pedagogy of Social Studies. Vol. 5 | No.1 | 2020 